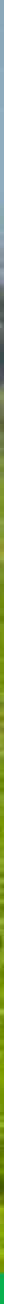

\title{
Pachtnormen 2016
}

Berekening hoogst toelaatbare pachtprijzen voor los land, agrarische bedrijfsgebouwen en agrarische woningen

H.J. Silvis, R.W. van der Meer en M.J. Voskuilen

LE I

WAGENINGENUR 


\section{Pachtnormen 2016}

Berekening hoogst toelaatbare pachtprijzen voor los land, agrarische bedrijfsgebouwen en agrarische woningen

H.J. Silvis, R.W. van der Meer en M.J. Voskuilen

Dit onderzoek is uitgevoerd door LEI Wageningen UR in opdracht van en gefinancierd door het ministerie van Economische Zaken.

LEI Wageningen UR

Wageningen, mei 2016

NOTA

LEI 2016-053

LE I 
Silvis, H.J., R.W. van der Meer en M.J. Voskuilen. Pachtnormen 2016; Berekening hoogst toelaatbare pachtprijzen voor los land, agrarische bedrijfsgebouwen en agrarische woningen. Wageningen, LEI Wageningen UR (University \& Research centre), LEI Nota 2016-053. 26 blz.; 1 fig.; 21 tab.; 12 ref.

In opdracht van het ministerie van Economische Zaken heeft LEI Wageningen UR de hoogst toelaatbare pachtprijzen voor 2016 berekend conform de uitgangspunten van het Pachtprijzenbesluit 2007. In de meeste pachtprijsgebieden gaan de pachtnormen vrij sterk omhoog ten opzichte van de pachtnormen 2015. Dit wordt verklaard doordat de gemiddelde grondbeloning in de periode 20102014 beduidend hoger is dan de gemiddelde grondbeloning over de periode 2009-2013.

Trefwoorden: pachtnormen, pachtprijsgebieden, grondbeloning, regionormen, agrarische bedrijfsgebouwen, agrarische woningen

Dit rapport is gratis te downloaden op http://dx.doi.org/10.18174/382678 of op www.wageningenUR.nl/lei (onder LEI publicaties).

\section{(C) 2016 LEI Wageningen UR}

Postbus 29703, 2502 LS Den Haag, T 07033583 30, E informatie.lei@wur.nl, www.wageningenUR.nl/lei. LEI is onderdeel van Wageningen UR (University \& Research centre).

\section{(cc) BY-NC}

LEI hanteert voor haar rapporten een Creative Commons Naamsvermelding 3.0 Nederland licentie.

(C) LEI, onderdeel van Stichting Dienst Landbouwkundig Onderzoek, 2016

De gebruiker mag het werk kopiëren, verspreiden en doorgeven en afgeleide werken maken. Materiaal van derden waarvan in het werk gebruik is gemaakt en waarop intellectuele eigendomsrechten berusten, mogen niet zonder voorafgaande toestemming van derden gebruikt worden. De gebruiker dient bij het werk de door de maker of de licentiegever aangegeven naam te vermelden, maar niet zodanig dat de indruk gewekt wordt dat zij daarmee instemmen met het werk van de gebruiker of het gebruik van het werk. De gebruiker mag het werk niet voor commerciële doeleinden gebruiken.

Het LEI aanvaardt geen aansprakelijkheid voor eventuele schade voortvloeiend uit het gebruik van de resultaten van dit onderzoek of de toepassing van de adviezen.

Het LEI is ISO 9001:2008 gecertificeerd.

LEI 2016-053

Foto omslag: Shutterstock 


\section{Inhoud}

Woord vooraf $\quad 5$

Samenvatting $\quad 6$

S.1 Belangrijkste uitkomsten $\quad 6$

$\begin{array}{lll}\text { S.2 Vraagstelling en methode } & 7\end{array}$

1 $\begin{array}{ll}\text { Inleiding } & 8\end{array}$

1.1 Achtergrond en doel $\quad 8$

1.2 Berekening pachtnormen los land 8

1.3 Berekening pachtnormen agrarische bedrijfsgebouwen en agrarische woningen 10

Grondbeloning, regionorm en veranderpercentage per pachtprijsgebied

2.1 Los bouw- en grasland

2.1.1 Grondbeloning op basis van de periode 2010-2014 11

2.1.2 Correctie voor vereiste directe rendement $\quad 12$

2.1.3 Regionorm en veranderpercentage in veertien pachtprijsgebieden $\quad 14$

$\begin{array}{lll}2.2 & \text { Los tuinland } & 15\end{array}$

2.2.1 Grondbeloning op basis van de periode 2010-2014 15

2.2.2 Correctie voor vereiste directe rendement 16

2.2.3 Regionorm en veranderpercentage voor twee pachtprijsgebieden 16

3 Hoogst toelaatbare pachtprijs agrarische bedrijfsgebouwen en agrarische woningen

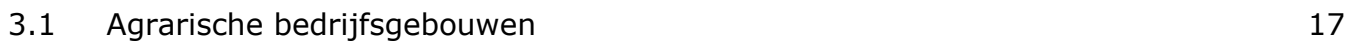

$\begin{array}{ll}3.2 & \text { Agrarische woningen } \\ \end{array}$

$\begin{array}{ll}\text { Literatuur en websites } & \mathbf{2 0}\end{array}$

Bijlage 1 Gemiddelde grondbeloning voor land- en tuinbouwbedrijven in de periode 2010-2014 



\section{Woord vooraf}

Het ministerie van Economische Zaken stelt jaarlijks de hoogst toelaatbare pachtprijzen vast voor akkerbouw- en grasland, tuinland, agrarische gebouwen en agrarische woningen. De nieuwe pachtnormen worden op 1 juli 2016 van kracht.

In opdracht van het ministerie van Economische Zaken heeft LEI Wageningen UR de hoogst toelaatbare pachtprijzen voor 2016 berekend conform de uitgangspunten van het Pachtprijzenbesluit 2007. In deze nota zijn de nieuwe pachtnormen opgenomen, inclusief een toelichting op de verschillende stappen in de berekeningen. Voor de meeste pachtprijsgebieden zijn de berekende pachtnormen voor 2016 fors hoger dan de pachtnormen van 2015.

Namens de opdrachtgever is het onderzoek begeleid door Liesbeth Kap van de directie Europees Landbouw- en Visserijbeleid en Voedselzekerheid van het ministerie van Economische Zaken, bijgestaan door Sanne van Keimpema van de directie Wetgeving Juridische Zaken van hetzelfde ministerie. Graag bedanken we beiden voor de constructieve samenwerking.

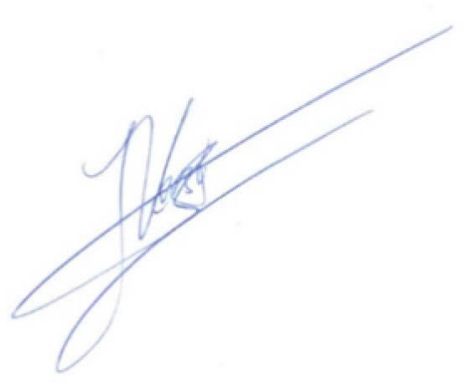

Prof. dr. ir. Jack (J.G.A.J.) van der Vorst Algemeen Directeur SSG Wageningen UR 


\section{Samenvatting}

\section{S.1 Belangrijkste uitkomsten}

De berekende pachtnormen voor 2016 zijn voor de meeste pachtprijsgebieden fors hoger dan de pachtnormen van 2015 (Tabel S.1). Dit wordt verklaard doordat de gemiddelde grondbeloning over de periode 2010-2014 (basis pachtnormen 2016) beduidend hoger is dan de gemiddelde grondbeloning over de periode 2009-2013 (basis pachtnormen 2015). Het jaar 2014, dat in de plaats komt van 2009, is dankzij de hoge melkprijs het beste inkomensjaar voor de melkveehouderij in de afgelopen jaren geworden. Daarentegen is 2009 de boeken ingegaan als een extreem slecht inkomensjaar voor de melkveehouderij. Voor de akkerbouwbedrijven geldt dat de grondbeloning in 2014 iets minder goed was dan 2009. Dat is vooral te wijten aan de lage prijs van consumptieaardappelen. De uitkomsten worden verder toegelicht in hoofdstuk 2.

Tabel S.1

Regionorm 2016, regionorm 2015 en veranderpercentage per pachtprijsgebied.

\begin{tabular}{|c|c|c|c|}
\hline Pachtprijsgebied & $\begin{array}{r}\text { Regionorm } 2016 \\
\text { (euro/ha) }\end{array}$ & $\begin{array}{r}\text { Regionorm } 2015 \\
\text { (euro/ha) }\end{array}$ & $\begin{array}{r}\text { Verander-percentage } \\
(\%)\end{array}$ \\
\hline \multicolumn{4}{|l|}{ Los bouw- en grasland } \\
\hline Bouwhoek en Hogeland & 836 & 714 & 17 \\
\hline Veenkoloniën en Oldambt & 806 & 689 & 17 \\
\hline Noordelijk weidegebied & 901 & 738 & 22 \\
\hline Oostelijk veehouderijgebied & 815 & 634 & 29 \\
\hline Centraal veehouderijgebied & 756 & 622 & 22 \\
\hline IJsselmeerpolders & 1.118 & 1.174 & -5 \\
\hline Westelijk Holland & 775 & 660 & 17 \\
\hline Waterland en Droogmakerijen & 527 & 394 & 34 \\
\hline Hollands/Utrechts weidegebied & 1.043 & 819 & 27 \\
\hline Rivierengebied & 986 & 836 & 18 \\
\hline Zuidwestelijk akkerbouwgebied & 667 & 708 & -6 \\
\hline Zuidwest-Brabant & 816 & 734 & 11 \\
\hline Zuidelijk veehouderijgebied & 901 & 751 & 20 \\
\hline Zuid-Limburg & 977 & 935 & 4 \\
\hline \multicolumn{4}{|l|}{ Los tuinland } \\
\hline Westelijk Holland & 2.652 & 2.380 & 11 \\
\hline Rest van Nederland & 1.073 & 811 & 32 \\
\hline
\end{tabular}

De berekende hoogst toelaatbare pachtprijzen in 2016 voor agrarische bedrijfsgebouwen (artikel 16 Pachtprijzenbesluit 2007) en de pachtprijs voor bestaande overeenkomsten (artikel 20) zijn 1,06\% hoger dan in 2015. Dit percentage is gelijk aan de gemiddelde bouwkostenindex over 2011-2015 (zie paragraaf 3.1).

De maximale pachtverhoging voor agrarische woningen met pachtovereenkomsten van vóór 1 september 2007 bedraagt 2,1\%. De hoogst toelaatbare pachtprijs voor agrarische woningen met pachtovereenkomsten op of na 1 september 2007 is eenmalig met 3,8\% naar beneden bijgesteld in verband met de aanpassing van het woningwaarderingsstelsel. Vervolgens is de hoogst toelaatbare pachtprijs voor agrarische woningen met 0,6\% verhoogd, het inflatiepercentage over 2015 (zie paragraaf 3.2). 


\section{S.2 Vraagstelling en methode}

Het ministerie van Economische Zaken heeft LEI Wageningen UR gevraagd om de pachtnormen voor 2016 te berekenen conform de uitgangspunten van het Pachtprijzenbesluit 2007. Het gaat hierbij om de normen voor los land (akkerbouw- en grasland), los tuinland, agrarische bedrijfsgebouwen en agrarische woningen. Volgens de wettelijke regeling van de pachtprijzen bestaan er twee soorten pachtnormen. Voor 'nieuwe' contracten - aangegaan op of na 1 september 2007 - geldt een maximale pachtprijs. Bestaande contracten - aangegaan vóór 1 september 2007 - worden aangepast met een percentage: het zogenaamde veranderpercentage.

\section{Berekeningswijze}

De pachtnormen voor los land en los tuinland worden jaarlijks bepaald op basis van een vijfjaarsgemiddelde van de opbrengst van het land, de grondbeloning, met een correctie voor de rendementseis van verpachters. De pachtnormen voor 2016 zijn gebaseerd op de gemiddelde grondbeloning over de jaren 2010-2014. Het veranderpercentage is gelijk aan de regionorm berekend over de periode 2010-2014 gedeeld door de regionorm berekend over de periode 2009-2013. Voor los land (akkerbouw en grasland) worden de pachtnormen gebaseerd op de grondbeloning van akkerbouw- en melkveebedrijven met een bepaalde omvang (zie paragraaf 1.2). De pachtnormen voor los land worden vastgesteld voor veertien gebieden: de pachtprijsgebieden. De pachtnormen voor los tuinland worden gebaseerd op de grondbeloning van opengrondstuinbouwbedrijven met een bepaalde omvang (zie paragraaf 1.2). Voor los tuinland zijn er twee pachtprijsgebieden vastgesteld.

De hoogst toelaatbare pachtprijzen voor nieuwe pachtovereenkomsten van agrarische bedrijfsgebouwen en de pachtprijs voor bestaande overeenkomsten worden gewijzigd met de bouwkostenindex (zie paragraaf 3.1).

De maximale pachtverhoging voor agrarische woningen met pachtovereenkomsten van vóór 1 september 2007 stijgt met het basishuurverhogingspercentage volgens het huurprijsbeleid woonruimte. De hoogst toelaatbare pachtprijs voor agrarische woningen met pachtovereenkomsten op of na 1 september 2007, wordt bepaald aan de hand van het puntenstelsel (zie paragraaf 3.2). 


\section{$1 \quad$ Inleiding}

\subsection{Achtergrond en doel}

Het ministerie van Economische Zaken stelt jaarlijks de hoogst toelaatbare pachtprijzen vast voor los ${ }^{1}$ akkerbouw- en grasland, los tuinland, agrarische bedrijfsgebouwen en agrarische woningen. De herziening van de pachtprijzen krijgt zijn beslag in de wijziging van de Uitvoeringsregeling pacht (van 2016). Voorzien is in de vaststelling van de hoogst toelaatbare pachtprijzen voor overeenkomsten die op of na 1 september 2007 zijn aangegaan en in de vaststelling van de percentages waarmee de geldende pachtprijzen voor overeenkomsten die zijn aangegaan vóór 1 september 2007 wijzigen (de zogenaamde 'veranderpercentages'). De nieuwe pachtnormen worden op 1 juli 2016 van kracht. LEI Wageningen UR heeft in opdracht van het ministerie van Economische Zaken de hoogst toelaatbare pachtprijzen voor 2016 berekend conform de uitgangspunten van het Pachtprijzenbesluit 2007, met inachtneming van het Besluit van 31 oktober 2013 tot wijziging van het Pachtprijzenbesluit 2007.

\subsection{Berekening pachtnormen los land}

Het Pachtprijzenbesluit 2007 maakt onderscheid in pachtnormen voor los land (akkerbouw- en grasland) en los tuinland. De eerste worden berekend voor veertien gebieden, de pachtprijsgebieden, en de tweede voor twee pachtprijsgebieden, Westelijk Holland en de Rest van Nederland. Westelijk Holland is een van de veertien pachtprijsgebieden. In Figuur 1.1 is de berekening van de pachtnormen uitgebeeld.

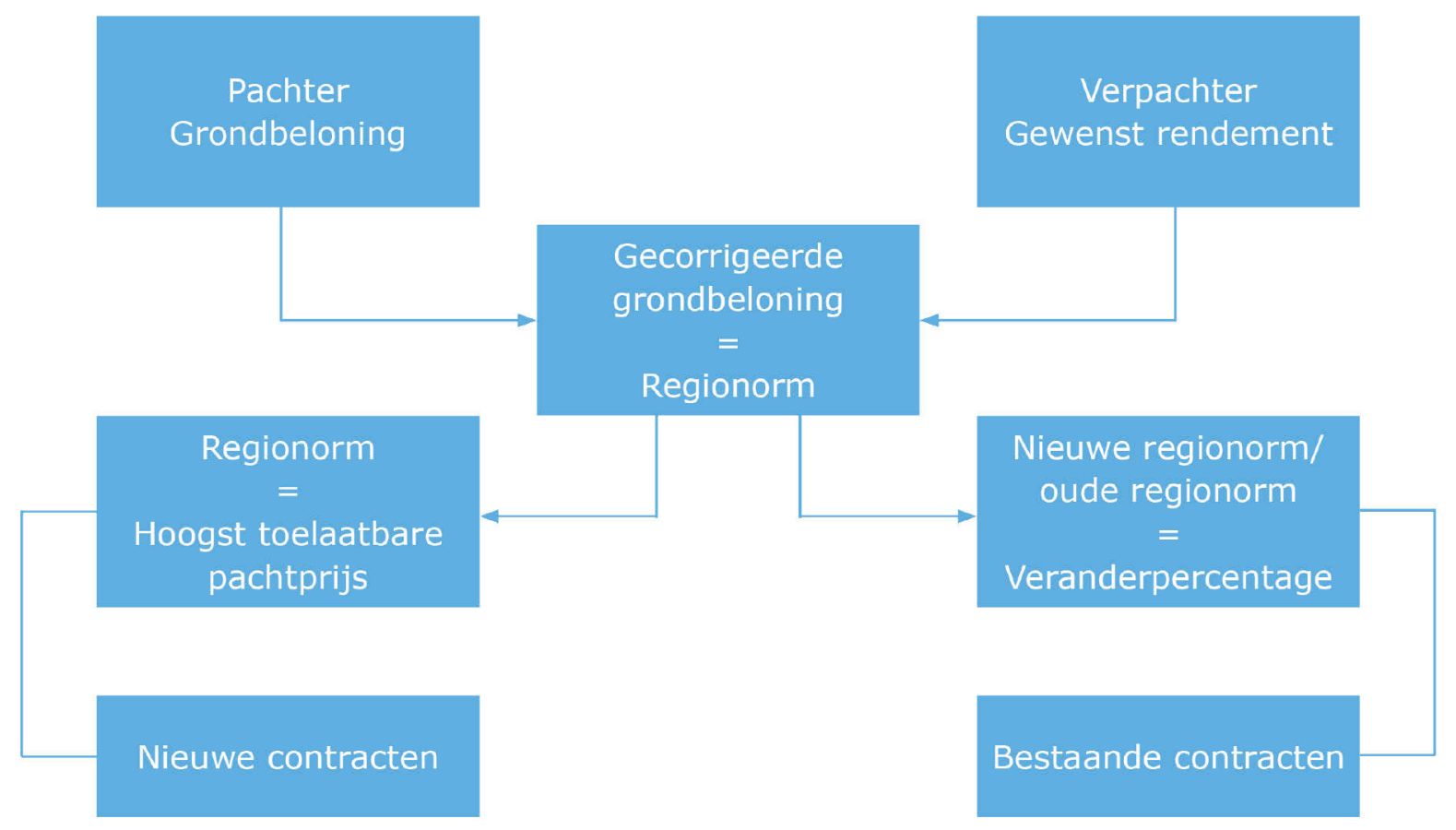

Figuur 1.1 Berekening hoogst toelaatbare pachtprijzen los land.

1 Land zonder woningen of andere opstallen. 
Voor pachtcontracten die vanaf 1 september 2007 zijn gesloten, geldt een maximale pachtprijs (regionorm). De berekening van deze regionorm is gebaseerd op de grondbeloning, waarbij rekening wordt gehouden met een reservering door de pachter. Hierop wordt een correctie toegepast als de vergelijking met de rendementseis voor de verpachter daartoe aanleiding geeft.

De berekening van de regionorm voor los bouw- en grasland gaat in de volgende stappen

(Figuur 1.1):

- Vaststelling van de gemiddelde 'grondbeloning per hectare voor reservering' in de periode 20102014 van akkerbouwbedrijven met een bedrijfsomvang van 130.000 tot 750.000 euro SO ${ }^{2}$ en van melkveebedrijven met een omvang van 155.000 tot 885.000 euro SO.

- Vaststelling van de 'grondbeloning per hectare na reservering'. Hiervoor wordt van de 'grondbeloning voor reservering' (uit de vorige stap) op bedrijfsniveau $20 \%$ afgetrokken voor reserveringen van de pachter (Figuur 1.1: linksboven). Als een bedrijf een negatieve grondbeloning heeft, wordt er geen bedrag voor reservering afgetrokken.

- Vaststelling van de regionorm door middel van een eventuele correctie van de grondbeloning (na reservering) in verband met het door verpachters gewenste (directe) rendement, zijnde een percentage van de prijs van verpachte landbouwgronden (Figuur 1.1: rechtsboven en midden).

Voor pachtcontracten die vóór 1 september 2007 zijn aangegaan, wordt de pachtprijs gewijzigd met een percentage. Dit veranderpercentage wordt bepaald door de relatieve verandering van de nieuwe regionorm ten opzichte van de oude regionorm (Figuur 1.1: rechtsonder).

Voor de berekening van de pachtnormen voor los tuinland worden dezelfde stappen doorlopen als die voor los bouw- en grasland. De basis wordt gevormd door de grondbeloning van opengrondstuinbouwbedrijven met een omvang van 155.000 tot 885.000 euro SO.

\section{Wijziging pachtprijsgebieden en berekening grondbeloning}

Per 1 januari 2014 zijn twee pachtprijsgebieden gewijzigd. Westelijk Holland is uitgebreid met de twee opgeheven gemeenten Wieringen en Wieringermeer. Deze gemeenten vormen samen met de twee andere opgeheven gemeenten Anna Paulowna en Niedorp de nieuwe gemeente Hollands Kroon. Het pachtprijsgebied IJsselmeerpolders gaat verder zonder de opgeheven gemeenten Wieringen en Wieringermeer. Door deze wijziging zijn de veertien pachtprijsgebieden niet langer gelijk aan de veertien groepen van landbouwgebieden.

Voor de berekening van de pachtnormen voor 2016 is de grondbeloning berekend over de periode 2010-2014. Voor Westelijk Holland is de grondbeloning van 2010 en 2011 gebaseerd op het 'oude' pachtprijsgebied Westelijk Holland en voor 2012, 2013 en 2014 op het 'nieuwe' pachtprijsgebied Westelijk Holland. Voor IJsselmeerpolders is de grondbeloning van 2010 en 2011 gebaseerd op het 'oude' pachtprijsgebied IJsselmeerpolders en voor 2012, 2013 en 2014 op het 'nieuwe' pachtprijsgebied IJsselmeerpolders (Tabel 1.1). Hiermee wordt invulling gegeven aan het besluit tot wijziging van het pachtprijzenbesluit 2007 d.d. 31 oktober 2013 (Staatsblad, 2013).

Tabel 1.1

Berekening hoogst toelaatbare pachtprijzen 2016 naar grondbeloningsjaar.

\begin{tabular}{lll} 
Pachtprijsgebied per 1-1-2014 & 2010 en 2011 & 2012,2013 en 2014 \\
IJsselmeerpolders & Gebiedsindeling IJsselmeerpolders & Gebiedsindeling IJsselmeerpolders \\
& geldend tot $1-1-2014$ & geldig per 1-1-2014 \\
\hline Westelijk Holland & Gebiedsindeling Westelijk Holland & Gebiedsindeling Westelijk Holland \\
& geldend tot $1-1-2014$ & geldig per 1-1-2014 \\
\hline
\end{tabular}

2 Standaardopbrengst, een maat voor de economische omvang van bedrijven; voor 2010 werd gewerkt met Nederlandse grootte-eenheden (nge). 


\subsection{Berekening pachtnormen agrarische bedrijfsgebouwen en agrarische woningen}

De berekening van de hoogst toelaatbare pachtprijzen van bestaande agrarische bedrijfsgebouwen waarvan de exploitatie gebeurt in direct verband met de oppervlakte grond (artikel 16 van het Pachtprijzenbesluit 2007) is na afstemming met vertegenwoordigers van pachters en verpachters met ingang van de Uitvoeringsregeling pachtprijzen van 2012 gewijzigd (Luijt et al., 2012). De hoogst toelaatbare pachtprijs voor pachtcontracten van agrarische bedrijfsgebouwen die vanaf 1 september 2007 zijn aangegaan, worden bepaald aan de hand van hectarenormen per bedrijfstype. Deze normen worden jaarlijks aangepast met de bouwkostenindex. De pachtprijs voor bestaande contracten van agrarische bedrijfsgebouwen (aangegaan vóór 1 september 2007) worden eveneens met de bouwkostenindex gewijzigd.

De maximale pachtverhoging voor agrarische woningen met een contract van vóór 1 september 2007 is gelijk aan het basishuurverhogingspercentage volgens het huurprijsbeleid woonruimte. Voor pachtovereenkomsten ingegaan op of na 1 september 2007 worden de hoogst toelaatbare pachtprijzen bepaald aan de hand van de maximale huurprijsgrenzen voor agrarische woningen. Deze worden geïndexeerd met het inflatiepercentage (zie paragraaf 3.2). 


\section{Grondbeloning, regionorm en veranderpercentage per pachtprijsgebied}

\subsection{Los bouw- en grasland}

\subsubsection{Grondbeloning op basis van de periode 2010-2014}

De pachtnormen voor 2016 zijn berekend op basis van de grondbeloning in de jaren 2010-2014. Tabel 2.1 geeft de gemiddelde grondbeloning per pachtprijsgebied weer voor de periode 2010-2014 (zie ook Bijlage 1). Deze grondbeloning is nog niet verminderd met de noodzakelijke vermogensgroei (de reservering) van het bedrijf van de pachter.

Tabel 2.1

Gemiddelde grondbeloning (euro per hectare) voor reservering naar pachtprijsgebied, 2010-2014.

\begin{tabular}{lrrrrrr} 
Pachtprijsgebied & 2010 & 2011 & 2012 & 2013 & 2014 & $\begin{array}{r}\text { Gemiddeld } \\
2010-2014\end{array}$ \\
Bouwhoek en Hogeland & 1.463 & 715 & 1.164 & 1.475 & 1.131 & 1.186 \\
\hline Veenkoloniën en Oldambt & 939 & 1.071 & 1.331 & 1.289 & 995 & 1.127 \\
\hline Noordelijk weidegebied & 1.123 & 1.403 & 1.042 & 1.546 & 1.172 & 1.257 \\
\hline Oostelijk veehouderijgebied & 889 & 1.186 & 1.042 & 1.416 & 1.254 & 1.159 \\
\hline Centraal veehouderijgebied & 890 & 811 & 734 & 1.510 & 1.041 & 1.007 \\
\hline IJsselmeerpolders & 2.147 & 598 & 2.772 & 2.071 & 643 & 1.591 \\
\hline Westelijk Holland & 1.099 & 860 & 1.167 & 1.366 & 983 & 1.095 \\
\hline Waterland en Droogmakerijen & 641 & 639 & 274 & 921 & 914 & 681 \\
\hline Hollands/Utrechts weidegebied & 1.313 & 1.704 & 1.037 & 1.589 & 1.620 & 1.459 \\
\hline Rivierengebied & 1.330 & 1.680 & 1.053 & 1.497 & 1.337 & 1.374 \\
\hline Zuidwestelijk akkerbouwgebied & 1.642 & 163 & 1.668 & 625 & 45 & 802 \\
\hline Zuidwest-Brabant & 741 & 1.037 & 1.174 & 1.660 & 798 & 1.085 \\
\hline Zuidelijk veehouderijgebied & 903 & 1.684 & 1.203 & 1.614 & 1.032 & 1.288 \\
\hline Zuid-Limburg & 1.354 & 1.176 & 1.935 & 1.478 & 938 & 1.366 \\
\hline Nederland & 1.175 & 1.125 & 1.230 & 1.425 & 1.018 & 1.195 \\
\hline
\end{tabular}

Bron: LEI Wageningen UR.

De pachtnormen voor 2016 zijn berekend op basis van de grondbeloning in de jaren 2010-2014; die van 2015 op basis van de grondbeloning in de jaren 2009-2013. Ter verklaring van de veranderingen moet dan ook gekeken worden naar de verschillen in grondbeloning tussen 2014 en 2009. De gemiddelde landelijke grondbeloning over de jaren 2010-2014 (1.195 euro per hectare, Tabel 2.1) ligt ruim boven die in de voorgaande periode 2009-2013 (1.022 euro).

Vooral de inkomensvorming in de melkveehouderij is in de meeste gebieden doorslaggevend. Het jaar 2014, dat in de plaats komt van 2009, is dankzij de hoge melkprijs het beste inkomensjaar voor de melkveehouderij in de afgelopen jaren geworden. Daarentegen is 2009 de boeken ingegaan als een extreem slecht inkomensjaar voor de melkveehouderij.

In de akkerbouw werd in 2014 gemiddeld minder verdiend dan in 2009. Hierdoor ligt de gemiddelde grondbeloning in 2010-2014 in de IJsselmeerpolders en het Zuidwestelijk akkerbouwgebied onder die in 2009-2013. Dat is vooral te wijten aan de lage prijs voor consumptieaardappelen in het seizoen 
2014-2015. Voor de zetmeelbedrijven was 2014 wel een beter jaar dan 2009. Daarom stijgt in het noordoosten de gemiddelde grondbeloning van de akkerbouwbedrijven.

Tabel 2.2 geeft de grondbeloning in de periode 2010-2014 weer nadat daarop 20\% reservering voor noodzakelijke vermogensgroei in mindering is gebracht. Echter, wanneer een bedrijf in enig jaar een negatieve grondbeloning realiseerde, is de reservering voor dat bedrijf in dat jaar niet toegepast. Dat heeft tot gevolg dat de bedragen in Tabel 2.2 niet gelijk zijn aan de bedragen van Tabel 2.1 minus $20 \%$. Omdat de reservering alleen wordt berekend voor bedrijven met een positieve grondbeloning is de reservering doorgaans hoger dan $20 \%$ van de grondbeloning.

\section{Tabel 2.2}

Gemiddelde grondbeloning (euro per hectare) na reservering a) naar pachtprijsgebied, 2010-2014.

\begin{tabular}{|c|c|c|c|c|c|c|}
\hline Pachtprijsgebied & 2010 & 2011 & 2012 & 2013 & 2014 & $\begin{array}{l}\text { Gemiddeld } \\
2010-2014\end{array}$ \\
\hline Bouwhoek en Hogeland & 1.167 & 542 & 894 & 1.170 & 887 & 929 \\
\hline Noordelijk weidegebied & 894 & 1.119 & 826 & 1.235 & 931 & 1.001 \\
\hline Oostelijk veehouderijgebied & 686 & 922 & 803 & 1.125 & 989 & 906 \\
\hline IJsselmeerpolders & 1.690 & 429 & 2.209 & 1.657 & 450 & 1.242 \\
\hline Westelijk Holland & 870 & 673 & 928 & 1.071 & 760 & 861 \\
\hline Waterland en Droogmakerijen & 494 & 504 & 183 & 726 & 715 & 527 \\
\hline Hollands/Utrechts weidegebied & 1.044 & 1.362 & 811 & 1.262 & 1.291 & 1.159 \\
\hline Zuidelijk veehouderijgebied & 655 & 1.332 & 947 & 1.276 & 788 & 1.001 \\
\hline Zuid-Limburg & 1.080 & 931 & 1.545 & 1.182 & 729 & 1.085 \\
\hline Nederland & 924 & 881 & 970 & 1.132 & 791 & 939 \\
\hline
\end{tabular}

a) Met ingang van de Regeling pachtprijzen 2011 is de reservering gesteld op $20 \%$ van de grondbeloning. Voor bedrijven die een negatieve grondbeloning realiseerden, is geen reservering berekend.

Bron: LEI Wageningen UR.

\subsubsection{Correctie voor vereiste directe rendement}

Het vereiste directe rendement is onderdeel van de berekening van de jaarlijkse pachtnormen, in de zin dat het een correctiefactor van de berekende grondbeloning kan zijn. De twee pijlers (grondbeloning en vereist direct rendement) worden door elkaar gedeeld en de uitkomst daarvan kan per pachtprijsgebied aanleiding zijn om de grondbeloning met 5 of $10 \%$ naar boven of beneden bij te stellen.

\section{Tabel 2.3}

Correctie grondbeloning op basis van de verhouding tussen de grondbeloning en het vereiste directe rendement van de verpachter.

\begin{tabular}{lr} 
Vereiste directe rendement/grondbeloning & Correctiefactor grondbeloning in \% \\
$<0,8$ & -10 \\
\hline $0,8-0,9$ & -5 \\
\hline $0,9-1,1$ & 0 \\
\hline $1,1-1,2$ & +5 \\
\hline 1,2 & +10
\end{tabular}

Bron: Artikel 9, eerste lid van het Pachtprijzenbesluit 2007. 
In Tabel 2.3 zijn de correctiefactoren opgenomen. Het werkt als volgt:

- Bij een afwijking van minder dan $10 \%$ tussen de grondbeloning en het vereiste directe rendement wordt geen correctie toegepast.

- Bij afwijkingen tussen 10 en 20\% wordt de grondbeloning met 5\% gecorrigeerd.

- Bij een afwijking van meer dan $20 \%$ wordt de grondbeloning met $10 \%$ gecorrigeerd.

Bij een verhouding kleiner dan 0,8 wordt de grondbeloning dus met $10 \%$ verlaagd, tussen 0,8 en 0,9 is de aftrek $5 \%$, tussen 0,9 en 1,1 vindt geen correctie plaats, tussen 1,1 en 1,2 wordt de grondbeloning met $5 \%$ verhoogd en bij een verhouding groter dan 1,2 wordt de grondbeloning met $10 \%$ verhoogd.

Het door verpachters vereiste directe rendement (artikel 9 van het Pachtprijzenbesluit 2007) wordt afgeleid van het rendement van risicomijdende vastrentende waarden. Het wordt berekend door het driejarig voortschrijdend gemiddelde van de reële lange kapitaalmarktrente, zijnde het effectief rendement van de 10-jarige Euro Interest Rate Swap (Euro IRS) van december 2015 (1,421\%), te verminderen met het driejarig voortschrijdend gemiddelde van de inflatie in de eurozone per december 2015 (gebaseerd op de HCIP, de geharmoniseerde Europese consumentenprijsindex) van 0,257\%, te vermeerderen met een opslag voor grondlasten, beheerkosten, belastingen en risico van 1,25\%. Daarmee komt het vereiste directe rendement voor de Uitvoeringsregeling Pachtprijzen van 2016 op $(1,421 \%-0,257 \%+1,25 \%=) 2,414 \%$ van de verpachte waarde dan wel de helft daarvan $(1,207 \%)$ voor de onverpachte waarde. ${ }^{3}$

\section{Tabel 2.4}

Grondprijs, minimaal vereist direct rendement, grondbeloning (euro per hectare) en verhouding rendementseis en grondbeloning.

\begin{tabular}{|c|c|c|c|c|}
\hline Pachtprijsgebied & $\begin{array}{r}\text { Prijs onverpachte } \\
\text { grond } 2014 \text { a) }\end{array}$ & $\begin{array}{l}\text { Vereiste directe } \\
\text { rendement b) }\end{array}$ & $\begin{array}{r}\text { Grondbeloning } \\
2010-2014 \mathrm{c})\end{array}$ & $\begin{array}{c}\text { Rendementseis/ } \\
\text { grondbeloning }\end{array}$ \\
\hline Bouwhoek en Hogeland & 46.595 & 562 & 929 & 0,60 \\
\hline Noordelijk weidegebied & 41.603 & 502 & 1.001 & 0,50 \\
\hline Oostelijk veehouderijgebied & 52.798 & 637 & 906 & 0,70 \\
\hline IJsselmeerpolders & 73.781 & 891 & 1.242 & 0,72 \\
\hline Westelijk Holland & 51.904 & 626 & 861 & 0,73 \\
\hline Waterland en Droogmakerijen & 46.610 & 563 & 527 & 1,07 \\
\hline Hollands/Utrechts weidegebied & 50.496 & 609 & 1.159 & 0,53 \\
\hline Zuidelijk veehouderijgebied & 62.616 & 756 & 1.001 & 0,76 \\
\hline Zuid-Limburg & 52.397 & 632 & 1.085 & 0,58 \\
\hline
\end{tabular}

a) Bron: Kadaster/RVO/LEI Wageningen UR; b) 1,207\% van de prijs van onverpachte landbouwgrond; c) Bron: LEI Wageningen UR.

De nominale rente (IRS) is gedaald van ongeveer $1,8 \%$ in 2014 naar $1,4 \%$ in 2015 . De inflatie is in 2015 echter nog sterker afgenomen, waardoor de reële rente (IRS minus inflatie) is gestegen: van $0,9 \%$ eind 2014 tot $1,2 \%$ eind 2015 . Dat is overigens nog lager dan enkele jaren geleden. Zo bedroeg de reële rente eind 2010 2,2\%.

In het merendeel van de gebieden (tien van de veertien) ligt de rendementseis ruim onder de grondbeloning (Tabel 2.4), met als gevolg dat de grondbeloning met $10 \%$ wordt verlaagd (Tabel 2.5). Deze gecorrigeerde grondbeloning is de nieuwe regionorm.

${ }^{3}$ De prijs van regulier verpachte landbouwgrond is gelijkgesteld aan de helft van de prijs van onverpachte landbouwgrond. 
Tabel 2.5

Berekening regionorm 2016 per pachtprijsgebied: grondbeloning gecorrigeerd voor rendementseis.

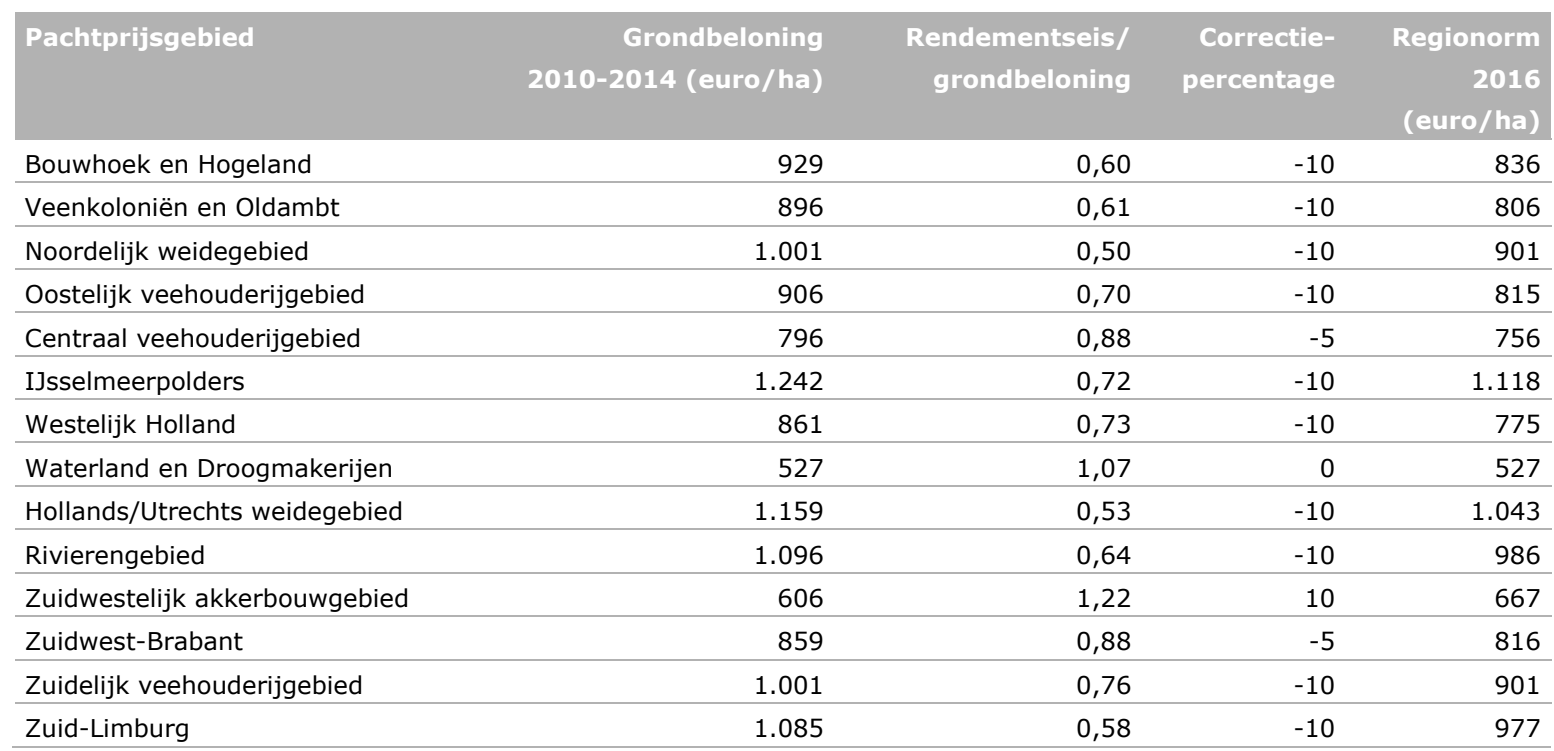

\subsubsection{Regionorm en veranderpercentage in veertien pachtprijsgebieden}

In Tabel 2.6 zijn per pachtprijsgebied de nieuwe regionorm (2016), de oude regionorm (2015) en het absolute en relatieve verschil tussen beide vermeld. De pachtnormen 2016 stijgen in de meeste gebieden vrij sterk ten opzichte van de pachtnormen 2015. Ze zijn gebaseerd op de gemiddelde grondbeloning in de periode 2010-2014, tegenover de periode 2009-2013 voor de pachtnormen 2015. De veranderingen in de pachtnormen 2016 ten opzichte van de pachtnormen 2015 zijn dan ook bepaald door de verschillen in de berekende grondbeloning voor 2014 en 2009 (zie paragraaf 2.1.1). Zonder de correctie voor de rendementseis (zie paragraaf 2.1.2) zou de regionorm nog meer zijn gestegen.

Tabel 2.6

Regionorm 2016, regionorm 2015 en veranderpercentage per pachtprijsgebied.

\begin{tabular}{|c|c|c|c|c|}
\hline Pachtprijsgebied & $\begin{array}{r}\text { Regionorm } 2016 \\
\text { (euro/ha) }\end{array}$ & $\begin{array}{r}\text { Regionorm } 2015 \\
\text { (euro/ha) }\end{array}$ & $\begin{array}{r}\text { Verschil } \\
\text { (euro/ha) }\end{array}$ & $\begin{array}{r}\text { Verander- } \\
\text { percentage }(\%)\end{array}$ \\
\hline Bouwhoek en Hogeland & 836 & 714 & 122 & 17 \\
\hline Veenkoloniën en Oldambt & 806 & 689 & 117 & 17 \\
\hline Noordelijk weidegebied & 901 & 738 & 163 & 22 \\
\hline Oostelijk veehouderijgebied & 815 & 634 & 181 & 29 \\
\hline Centraal veehouderijgebied & 756 & 622 & 134 & 22 \\
\hline IJsselmeerpolders & 1.118 & 1.174 & -56 & -5 \\
\hline Westelijk Holland & 775 & 660 & 115 & 17 \\
\hline Waterland en Droogmakerijen & 527 & 394 & 133 & 34 \\
\hline Hollands/Utrechts weidegebied & 1.043 & 819 & 224 & 27 \\
\hline Rivierengebied & 986 & 836 & 150 & 18 \\
\hline Zuidwestelijk akkerbouwgebied & 667 & 708 & -41 & -6 \\
\hline Zuidwest-Brabant & 816 & 734 & 82 & 11 \\
\hline Zuidelijk veehouderijgebied & 901 & 751 & 150 & 20 \\
\hline Zuid-Limburg & 977 & 935 & 42 & 4 \\
\hline
\end{tabular}

In de pachtprijsgebieden met een stijging van het veranderpercentage moet in individuele gevallen worden nagegaan of de te betalen pacht niet uitstijgt boven $110 \%$ van de regionorm. Is dat het geval, 
dan is de maximale pachtprijs gelijk aan $110 \%$ van de regionorm. Als in individuele gevallen de laatst betaalde pacht al hoger is dan de nieuwe regionorm, wordt de betaalde pacht bevroren.

Daarnaast moet worden nagegaan of in individuele gevallen de pachtprijs van de betreffende percelen niet hoger is dan $2 \%$ van de vrije grondprijs van die percelen. Is dat het geval, dan is $2 \%$ van de vrije grondprijs de maximaal te betalen pachtprijs. De laagste van beide plafonds geldt.

In de pachtprijsgebieden met een daling van het veranderpercentage dient in individuele gevallen te worden nagegaan of de daling mag worden geëffectueerd. Alleen als de laatst betaalde pachtprijs in die pachtprijsgebieden al hoger is dan $90 \%$ van de nieuwe regionorm, mag de daling worden toegepast, mits de bodemwaarde van $90 \%$ van de nieuwe regionorm niet wordt overschreden. Is de laatst betaalde pachtprijs al lager dan $90 \%$ van de nieuwe regionorm, dan blijft de pachtprijs gelijk (wordt bevroren).

\subsection{Los tuinland}

\subsubsection{Grondbeloning op basis van de periode 2010-2014}

Voor tuinland worden twee gebieden onderscheiden, Westelijk Holland (exclusief het gebied Boskoop en Rijneveld) en de rest van Nederland. Deze tweedeling komt tegemoet aan de diversiteit van de tuinbouw (Bijlage 1). De grondbeloning van in Boskoop gelegen boomkwekerijbedrijven wordt bij de berekeningen niet meegenomen, omdat die qua hoogte niet in verhouding staat tot de grondbeloning van de andere opengrondstuinbouwbedrijven. Hetzelfde geldt voor de intensiteit van het grondgebruik (nge/ha of SO/ha). Die is in de opengrondstuinbouw van Boskoop 4,5 keer zo hoog als elders.

Aangezien reguliere pacht in de regio Boskoop nauwelijks voorkomt, wordt er geen aparte pachtnorm voor Boskoop (en Rijneveld) berekend. Voor zover nieuwe reguliere pachtovereenkomsten in Boskoop (en Rijneveld) worden afgesloten, geldt de regionorm voor tuinland in Westelijk Holland. Voor bestaande reguliere pachtcontracten geldt het veranderpercentage van Westelijk Holland.

In Tabel 2.7 is de grondbeloning vóór reservering opgenomen en in Tabel 2.8 die na reservering. Evenals in het geval van los akkerbouw- en grasland bedraagt de reservering $20 \%$ van de grondbeloning (van Tabel 2.7) en is de reservering op nul gesteld wanneer een bedrijf een negatieve grondbeloning realiseerde (alleen in het jaar waarin zich dat voordeed).

\section{Tabel 2.7}

Grondbeloning (euro per hectare) voor reservering, 2010-2014.

\begin{tabular}{lcccccr} 
Pachtprijsgebied & 2010 & 2011 & 2012 & 2013 & 2014 & $\begin{array}{r}\text { Gemiddeld } \\
2010-2014\end{array}$ \\
Westelijk Holland a) & 4.530 & 1.714 & 4.655 & 4.866 & 2.883 & 3.774 \\
\hline Rest van Nederland & -725 & 1.191 & 1.694 & 4.066 & 3.332 & 1.813 \\
\hline
\end{tabular}

a) Exclusief boomkwekerij in het gebied Boskoop en Rijneveld.

Bron: LEI Wageningen UR.

In Westelijk Holland is de gemiddelde grondbeloning gestegen van 3.422 euro per hectare in de periode 2009-2013 tot 3.774 euro in de jaren 2010-2014 (Tabel 2.7); ook in het pachtprijsgebied Rest van Nederland nam de grondbeloning toe: van 1.372 tot 1.813 euro per hectare.

De grondbeloning is hoger doordat een matig inkomensjaar (2009) voor de vollegrondsgroenten- en bloembollenbedrijven is vervangen door een jaar (2014) met goede resultaten. Ook in de boomkwekerij was het inkomen in 2014 hoger dan in 2009. 
Tabel 2.8

Grondbeloning (euro per hectare) na reservering, 2010-2014.

$\begin{array}{lrrrrr}\text { Pachtprijsgebied } & 2010 & 2011 & 2012 & 2013 & 2014 \\ \text { Westelijk Holland a) } & & & & \text { Gemiddeld } \\ 2010-2014\end{array}$

a) Exclusief boomkwekerij in het gebied Boskoop en Rijneveld.

Bron: LEI Wageningen UR.

De samenstelling van de tuinbouwsector in beide gebieden verschilt overigens sterk. In Westelijk Holland is het merendeel bloembollenbedrijf. In Rest van Nederland spelen bloembollenbedrijven nauwelijks een rol en zijn de boomkwekerijen in de meerderheid.

\subsubsection{Correctie voor vereiste directe rendement}

De grondbeloning in Westelijk Holland ligt fors hoger dan de rendementseis, waardoor de grondbeloning met $10 \%$ naar beneden wordt bijgesteld tot 2.652 euro per hectare, de regionorm voor 2016 (Tabel 2.9). Ook in Rest van Nederland ligt de grondbeloning ruim boven de rendementseis, waardoor de grondbeloning met $10 \%$ wordt verlaagd tot 1.073 euro per hectare, de regionorm voor 2016 .

\section{Tabel 2.9}

Berekening regionorm per pachtprijsgebied: grondbeloning gecorrigeerd voor rendementseis.

\begin{tabular}{|c|c|c|c|c|c|c|}
\hline $\begin{array}{l}\text { Pachtprijs- } \\
\text { gebied }\end{array}$ & $\begin{array}{r}\text { Prijs } \\
\text { onverpacht } \\
\text { tuinland } 2014 \\
\text { (euro/ha) }\end{array}$ & $\begin{array}{r}\text { Vereiste } \\
\text { directe } \\
\text { rendement b) } \\
\text { (euro/ha) }\end{array}$ & $\begin{array}{r}\text { Grondbeloning } \\
2010-2014 \\
\text { (euro/ha) }\end{array}$ & $\begin{array}{l}\text { Rendementseis/ } \\
\text { grondbeloning } \\
\text { (kolom 2/kolom 3) }\end{array}$ & $\begin{array}{l}\text { Correctie- } \\
\text { percentage }\end{array}$ & $\begin{array}{r}\text { Regionorm } \\
2016 \\
\text { (euro/ha) }\end{array}$ \\
\hline $\begin{array}{l}\text { Westelijk } \\
\text { Holland a) }\end{array}$ & 76.841 & 927 & 2.947 & 0,31 & -10 & 2.652 \\
\hline $\begin{array}{l}\text { Rest van } \\
\text { Nederland }\end{array}$ & 73.687 & 889 & 1.192 & 0,75 & -10 & 1.073 \\
\hline
\end{tabular}

a) Exclusief boomkwekerij in het gebied Boskoop en Rijneveld; b) 1,207\% (zie paragraaf 2.1.2).

\subsubsection{Regionorm en veranderpercentage voor twee pachtprijsgebieden}

In Tabel 2.10 zijn de regionorm en het veranderpercentage voor 2016 opgenomen. De regionorm geldt voor nieuwe contracten; het veranderpercentage voor bestaande contracten. Voor toepassing van de veranderpercentages in individuele gevallen, zie paragraaf 2.1.3.

Tabel 2.10

Regionorm 2016, regionorm 2015 en veranderpercentage per pachtprijsgebied.

\begin{tabular}{lrrr} 
Pachtprijsgebied & $\begin{array}{r}\text { Regionorm 2016 } \\
\text { (euro/ha) }\end{array}$ & $\begin{array}{r}\text { Regionorm 2015 } \\
\text { (euro/ha) }\end{array}$ & $\begin{array}{r}\text { Verander- } \\
\text { percentage }(\%)\end{array}$ \\
Westelijk Holland a) & 2.652 & 2.380 & 11 \\
\hline Rest van Nederland & 1.073 & 811 & 32 \\
\hline
\end{tabular}

a) Exclusief boomkwekerij in het gebied Boskoop en Rijneveld. 


\section{Hoogst toelaatbare pachtprijs agrarische bedrijfsgebouwen en agrarische woningen}

\subsection{Agrarische bedrijfsgebouwen}

De hoogst toelaatbare pachtprijzen voor bedrijfsgebouwen in 2016 zijn berekend volgens de methode weergegeven in Luijt et al. (2012), die voor het eerst in 2012 is toegepast. Er is uitgegaan van drie bedrijfstypen, te weten: akkerbouwbedrijven, melkveebedrijven en overige bedrijven (Tabel 3.1). Deze drie bedrijfstypen verschillen substantieel voor wat betreft de soorten bedrijfsgebouwen, de nieuwwaarde daarvan en het gemiddelde bedrijfsareaal.

De hectarenormen van Tabel 3.1 zijn gebaseerd op de kosten van de bedrijfsgebouwen. Aangezien de kosten samenhangen met de leeftijd van de bedrijfsgebouwen is de leeftijd gebruikt voor een indeling in zes doelmatigheidscategorieën. Een gebouw met een leeftijd van 1 tot en met 7 jaar kan in het algemeen worden ingedeeld in de categorie 'nieuw'. Een gebouw met een leeftijd van 8 tot en met 14 jaar past over het algemeen het best in de categorie 'zeer goed'. Een gebouw met een leeftijd van 15 tot en met 21 jaar past over het algemeen het best in de categorie 'goed'. Een gebouw met een leeftijd van 21 tot en met 28 jaar past over het algemeen het best in de categorie 'redelijk'. Een gebouw met een leeftijd van 28 tot en met 35 jaar past over het algemeen het best in de categorie 'matig'. Een gebouw dat ouder is dan 35 jaar past over het algemeen het best in de categorie 'slecht'. Wat deze indeling betreft kunnen uitzonderingen gerechtvaardigd zijn als de doelmatigheid beter of slechter is dan wat doorgaans verwacht wordt van een bedrijfsgebouw van een bepaalde leeftijd. Te denken valt onder meer aan situaties waarbij tussentijdse investeringen door de verpachter in het bedrijfsgebouw zijn gedaan; de aanwezigheid van meerdere bedrijfsgebouwen in een complex (waardoor niet één leeftijd vastgesteld kan worden); zeer goed of juist slecht onderhoud gepleegd door de verpachter; de kwaliteit van de gebruikte materialen en constructie bij de bouw van het bedrijfsgebouw; afspraken tussen partijen; de aanwezigheid van meer (opslag)ruimten, stallen en aansluitingen dan gemiddeld, enzovoort.

Omdat de hectarenormen zijn berekend door de gebouwenkosten te delen door het gehele bedrijfsareaal, dient in afwijking van de 'oude' situatie in alle gevallen het areaal dat met behulp van de aanwezige bedrijfsgebouwen kan worden geëxploiteerd te worden aangehouden. Bij de vaststelling van het aantal hectaren moet rekening worden gehouden met de totale oppervlakte land waarvoor de bedrijfsgebouwen naar redelijke verwachting zullen worden geëxploiteerd.

Tabel 3.1

Hoogst toelaatbare pachtprijs (euro per hectare) bedrijfsgebouwen naar aard van het bedrijf, 2016.

\begin{tabular}{lrrrrrrr} 
& \multicolumn{9}{c}{ Aard van het bedrijf } & Noelmatigheid & & Matig & Slecht \\
\cline { 2 - 8 } Akkerbouw & 469 & 369 & 281 & 207 & 145 & 84 \\
\hline Melkvee & 1.205 & 948 & 724 & 532 & 370 & 212 \\
\hline Overig & 725 & 572 & 436 & 320 & 223 & 127 \\
\hline
\end{tabular}

Bron: Uitvoeringsregeling pachtprijzen 2015.

De hoogst toelaatbare pachtprijzen voor bedrijfsgebouwen (hectarenormen, Tabel 3.1) worden jaarlijks aangepast met behulp van de bouwkostenindex. Deze index berekent het LEI jaarlijks voor het Informatienet op basis van gegevens van het CBS. Voor de aanpassing wordt de gemiddelde bouwkostenindex genomen in de vijf jaar voorafgaand aan het jaar waarin de nieuwe hectarenormen 
van kracht worden (artikel 16 Pachtprijzenbesluit 2007). Voor 2016 is dat de gemiddelde index over 2011-2015, die uitkomt op 1,06\%.

De pachtprijs voor bestaande overeenkomsten wordt met hetzelfde percentage $(1,06 \%)$ gewijzigd (artikel 20 Pachtprijzenbesluit 2007).

\subsection{Agrarische woningen}

\section{Geschiedenis}

De huidige berekening van de hoogst toelaatbare pachtprijzen voor agrarische woningen vindt haar oorsprong in het Pachtnormenbesluit 1995. Toen heeft de minister van LNV het puntenstelsel van het ministerie van VROM voor niet-agrarische woningen overgenomen. Die punten dienden in dat jaar speciaal voor agrarische woningen met 5 gulden per punt te worden vermenigvuldigd. Bij het Pachtnormenbesluit 1998 kwam daar 80 cent per punt bij en werd elk punt met 5,80 gulden vermenigvuldigd. Bij het Pachtnormenbesluit 2001 kwam er nog eens 85 cent bij, waardoor elk punt met 6,65 gulden (3,02 euro) werd vermenigvuldigd. Aangezien het Pachtnormenbesluit om de drie jaar werd aangepast, stond er in 2004 weer een nieuw Pachtnormenbesluit in de steigers. Dat besluit is echter nooit geëffectueerd. De methode van berekenen is toen niet inhoudelijk, maar wel in technische zin gewijzigd. Vanaf 2004 werden de bedragen voor elk aantal punten (van 40 tot en met 250) gebaseerd op de 'Maximale huurprijsgrenzen voor zelfstandige woningen', met dien verstande dat een agrarische woning een aftrek kreeg van 0,34 euro per punt. Deze aftrek vond zijn oorsprong in het gegeven dat agrarische woningen doorgaans wat ruimer zijn en daardoor op een relatief hoog puntentotaal uitkomen. In 2007 werd dezelfde werkwijze gevolgd als in 2004. Uitgangspunt in dat jaar was de 'Maximale huurprijsgrenzen voor zelfstandige woningen per 1 juli 2007'. Per punt werd weer 0,34 euro in mindering gebracht voor agrarische woningen.

\section{Pachtprijzenbes/uit 2007}

In het Pachtprijzenbesluit 2007 worden in hoofdstuk 3 de pachtprijzen van agrarische woningen geregeld, waarbij onderscheid wordt gemaakt tussen overeenkomsten die op of na 1 september 2007 zijn ingegaan (artikel 14) en overeenkomsten die vóór 1 september 2007 zijn ingegaan (artikel 15).

Voor pachtovereenkomsten ingegaan op of na 1 september 2007 (artikel 14) worden hoogst toelaatbare pachtprijzen bepaald aan de hand van het puntenstelsel (Tabel 3.2). Daarbij wordt uitgegaan van de Uitvoeringswet huurprijzen woonruimte. Voor zelfstandige woningen worden jaarlijks maximale huurprijsgrenzen vastgesteld. De maximale huurprijsgrenzen worden op basis van artikel 12, lid 2 van het Besluit huurprijzen woonruimte jaarlijks geïndexeerd met het inflatiepercentage (van het voorafgaande jaar). Dat betekent dat ook de maximale huurprijsgrenzen voor agrarische woningen met het inflatiepercentage worden geïndexeerd. In artikel 14, lid 3 van het Pachtprijzenbesluit 2007 is verder opgenomen dat bij de vaststelling van de hoogst toelaatbare pachtprijzen rekening wordt gehouden met het agrarisch gebruik van de woningen. Dat is bij het vaststellen van de maximale huurprijsgrenzen in 2007 gedaan door een aftrek van 0,34 euro per punt toe te passen (Staatscourant, 2007). Door de jaarlijkse indexering van de maximale huurprijsgrenzen met het inflatiepercentage wordt impliciet ook de aftrek van 0,34 euro per punt voor agrarische woningen aangepast met het inflatiepercentage.

Voor pachtovereenkomsten ingegaan vóór 1 september 2007 (artikel 15) wordt de pachtprijs van een agrarische woning jaarlijks aangepast met een percentage dat overeenkomt met de indexering die wordt toegepast bij uitvoering van de regels bedoeld in artikel 14, derde lid van het Pachtprijzenbesluit 2007. Dat betekent volgens de juridische afdeling van het ministerie van Economische Zaken een percentage dat is vastgesteld op grond van de Uitvoeringswet huurprijzen woonruimte, rekening houdend met het agrarisch gebruik van de woningen. De maximale pachtverhoging in bestaande overeenkomsten voor agrarische woningen bedraagt 2,1\% (inflatie van 0,6\% plus 1,5\%), het basishuurverhogingspercentage volgens het huurprijsbeleid (BZK, 2016). Een extra verhoging voor inkomens boven de 34.678 euro, zoals met het stelsel onder de Uitvoeringswet huurprijzen beoogd, ligt niet voor de hand, omdat de met dit stelsel beoogde doorstroming bij agrarisch gebruik van woningen door de gebondenheid aan het bedrijf zich niet voordoet. 
Maximale huurprijsgrenzen voor agrarische woningen per 1 juli 2016

De maximale huurprijsgrenzen voor agrarische woningen worden afgeleid van de 'Maximale

huurprijsgrenzen voor zelfstandige woonruimten'. Per 1 oktober 2015 zijn deze eenmalig aangepast met $-3,8 \%$ in verband met de aanpassing van het woningwaarderingsstelsel (WWS) (BZK, 2015). Per 1 juli 2016 stijgen de huurprijsgrenzen met 0,6\% (inflatiepercentage over 2015; BZK, 2016). Door de maximale huurprijsgrenzen voor agrarische woningen van 2015 (Uitvoeringsregeling pacht, ingaande 1 juli 2015) eerst te verlagen met 3,8\% en vervolgens te verhogen met 0,6\% zijn de maximale huurprijsgrenzen voor 2016 bepaald (Tabel 3.2).

Tabel 3.2

Maximale huurprijsgrenzen voor agrarische woningen, 2016.

\begin{tabular}{|c|c|c|c|c|c|c|c|c|c|}
\hline Punten & Bedrag & Punten & Bedrag & Punten & Bedrag & Punten & Bedrag & Punten & Bedrag \\
\hline 40 & 173,15 & 82 & 355,82 & 124 & 556,95 & 166 & 758,06 & 208 & 959,16 \\
\hline 41 & 177,46 & 83 & 360,61 & 125 & 561,74 & 167 & 762,85 & 209 & 963,96 \\
\hline 42 & 181,81 & 84 & 365,39 & 126 & 566,51 & 168 & 767,62 & 210 & 968,77 \\
\hline 43 & 186,15 & 85 & 370,18 & 127 & 571,31 & 169 & 772,43 & 211 & 973,52 \\
\hline 44 & 190,45 & 86 & 374,97 & 128 & 576,10 & 170 & 777,20 & 212 & 978,32 \\
\hline 45 & 194,79 & 87 & 379,76 & 129 & 580,90 & 171 & 782,01 & 213 & 983,11 \\
\hline 46 & 199,12 & 88 & 384,56 & 130 & 585,69 & 172 & 786,78 & 214 & 987,90 \\
\hline 47 & 203,45 & 89 & 389,34 & 131 & 590,47 & 173 & 791,58 & 215 & 992,69 \\
\hline 48 & 207,78 & 90 & 394,15 & 132 & 595,25 & 174 & 796,34 & 216 & 997,48 \\
\hline 49 & 212,10 & 91 & 398,92 & 133 & 600,05 & 175 & 801,16 & 217 & $1.002,26$ \\
\hline 50 & 216,43 & 92 & 403,71 & 134 & 604,83 & 176 & 805,91 & 218 & $1.007,04$ \\
\hline 51 & 220,74 & 93 & 408,50 & 135 & 609,63 & 177 & 810,73 & 219 & $1.011,84$ \\
\hline 52 & 225,09 & 94 & 413,28 & 136 & 614,40 & 178 & 815,51 & 220 & $1.016,65$ \\
\hline 53 & 229,41 & 95 & 418,07 & 137 & 619,21 & 179 & 820,31 & 221 & $1.021,41$ \\
\hline 54 & 233,75 & 96 & 422,88 & 138 & 623,97 & 180 & 825,09 & 222 & $1.026,22$ \\
\hline 55 & 238,06 & 97 & 427,64 & 139 & 628,78 & 181 & 829,89 & 223 & $1.030,99$ \\
\hline 56 & 242,40 & 98 & 432,43 & 140 & 633,56 & 182 & 834,65 & 224 & $1.035,78$ \\
\hline 57 & 246,72 & 99 & 437,23 & 141 & 638,35 & 183 & 839,46 & 225 & $1.040,59$ \\
\hline 58 & 251,05 & 100 & 442,00 & 142 & 643,11 & 184 & 844,24 & 226 & $1.045,37$ \\
\hline 59 & 255,38 & 101 & 446,80 & 143 & 647,92 & 185 & 849,04 & 227 & $1.050,15$ \\
\hline 60 & 259,73 & 102 & 451,59 & 144 & 652,71 & 186 & 853,82 & 228 & $1.054,96$ \\
\hline 61 & 264,04 & 103 & 456,38 & 145 & 657,50 & 187 & 858,62 & 229 & $1.059,73$ \\
\hline 62 & 268,36 & 104 & 461,17 & 146 & 662,30 & 188 & 863,40 & 230 & $1.064,51$ \\
\hline 63 & 272,67 & 105 & 465,95 & 147 & 667,06 & 189 & 868,20 & 231 & $1.069,31$ \\
\hline 64 & 277,01 & 106 & 470,75 & 148 & 671,85 & 190 & 872,99 & 232 & $1.074,09$ \\
\hline 65 & 281,32 & 107 & 475,53 & 149 & 676,68 & 191 & 877,78 & 233 & $1.078,88$ \\
\hline 66 & 285,67 & 108 & 480,33 & 150 & 681,44 & 192 & 882,55 & 234 & $1.083,66$ \\
\hline 67 & 289,98 & 109 & 485,12 & 151 & 686,24 & 193 & 887,35 & 235 & $1.088,46$ \\
\hline 68 & 294,31 & 110 & 489,89 & 152 & 691,02 & 194 & 892,15 & 236 & $1.093,25$ \\
\hline 69 & 298,66 & 111 & 494,70 & 153 & 695,79 & 195 & 896,93 & 237 & $1.098,03$ \\
\hline 70 & 302,95 & 112 & 499,47 & 154 & 700,59 & 196 & 901,70 & 238 & $1.102,82$ \\
\hline 71 & 307,31 & 113 & 504,26 & 155 & 705,39 & 197 & 906,49 & 239 & $1.107,61$ \\
\hline 72 & 311,62 & 114 & 509,06 & 156 & 710,17 & 198 & 911,29 & 240 & $1.112,39$ \\
\hline 73 & 315,97 & 115 & 513,85 & 157 & 714,96 & 199 & 916,08 & 241 & $1.117,19$ \\
\hline 74 & 320,28 & 116 & 518,62 & 158 & 719,74 & 200 & 920,87 & 242 & $1.121,97$ \\
\hline 75 & 324,62 & 117 & 523,43 & 159 & 724,54 & 201 & 925,66 & 243 & $1.126,76$ \\
\hline 76 & 328,93 & 118 & 528,21 & 160 & 729,31 & 202 & 930,43 & 244 & $1.131,55$ \\
\hline 77 & 333,26 & 119 & 532,99 & 161 & 734,12 & 203 & 935,21 & 245 & $1.136,34$ \\
\hline 78 & 337,61 & 120 & 537,78 & 162 & 738,89 & 204 & 940,02 & 246 & $1.141,12$ \\
\hline 79 & 341,93 & 121 & 542,57 & 163 & 743,67 & 205 & 944,79 & 247 & $1.145,92$ \\
\hline 80 & 346,25 & 122 & 547,35 & 164 & 748,48 & 206 & 949,60 & 248 & $1.150,71$ \\
\hline \multirow[t]{2}{*}{81} & 351,03 & 123 & 552,15 & 165 & 753,26 & 207 & 954,39 & 249 & $1.155,49$ \\
\hline & & & & & & & & 250 & $1.160,29$ \\
\hline
\end{tabular}

Bron: Uitvoeringsregeling pachtprijzen 2015 en ministerie BZK (2015 en 2016). 


\section{Literatuur en websites}

BZK (ministerie van Binnenlandse Zaken en Koninkrijksrelaties), Aanpassingen woningwaarderingsstelsel. Den Haag, 2015.

BZK (ministerie van Binnenlandse Zaken en Koninkrijksrelaties), Huurprijsbeleid voor de periode 1 juli 2016 tot en met 30 juni 2017. Den Haag, 2016.

CP (Commissie Pachtnormen), Evenwicht in pachtnormen. 2006.

CP (Commissie Pachtnormen II), De prijs van pacht. 2010.

ECB (European Central Bank), Interest Rate Swap (IRS). Statistical Data Warehouse. $<$ sdw.ecb.europa.eu>

ECB (European Central Bank), HICP Euro area, all-items excluding tobacco. Monthly index. Statistical Data Warehouse. <sdw.ecb.europa.eu>

Luijt, J., R.W. van der Meer en M.J. Voskuilen, Modernisering pachtnormen agrarische bedrijfsgebouwen. LEI-nota 12-059. LEI, onderdeel van Wageningen UR, Den Haag, 2012.

Pachtprijzenbesluit 2007. <wetten.overheid.nl>

Poppe, K.J., Het Bedrijven-Informatienet van A tot Z. Rapport 1.03.06. LEI Wageningen UR, Den Haag, 2003.

Staatsblad, Bes/uit van 31 oktober 2013 tot wijziging van het Pachtprijzenbes/uit 2007. Staatsblad 2013, 446.

Staatscourant, Regeling pachtprijzen. Jaargang 2007, nr. 168.

Uitvoeringsregeling pacht. <wetten.overheid.nl> 


\section{Bijlage 1 Gemiddelde grondbeloning voor land- en tuinbouwbedrijven in de periode 2010-2014}

Deze bijlage gaat kort in op enkele uitkomsten van de berekening van de grondbeloning die gebruikt wordt voor de Regeling pachtprijzen van 2016. Ze beschrijft de aantallen gebruikte steekproefbedrijven, de manier van weging, de berekeningsmethode en de landelijke resultaten.

\section{B1.1 Los bouw- en grasland}

Gebruikte steekproefbedrijven

Elk akkerbouwbedrijf in de Landbouwtelling tussen 130.000 tot 750.000 euro SO en elk melkveebedrijf met een omvang van 155.000 tot 885.000 euro SO met maximaal $25 \%$ niet-grondgebonden opbrengsten dient te worden gerepresenteerd. Daartoe zijn uit het Informatienet de volgende bedrijven geselecteerd: alle akkerbouwbedrijven met een omvang van 93.600 tot 842.600 euro SO met maximaal $25 \%$ niet-grondgebonden opbrengsten, en alle melkveebedrijven met een omvang tussen 110.700 tot 974.250 euro SO met maximaal $25 \%$ niet-grondgebonden opbrengsten

(Tabel B.1).

Tabel B.1

Aantal gebruikte steekproefbedrijven naar pachtprijsgebied, 2010-2014.

\begin{tabular}{lrrrrrr} 
Pachtprijsgebied & 2010 & 2011 & 2012 & 2013 & 2014 & Gemiddeld \\
Bouwhoek en Hogeland & 33 & 32 & 28 & 28 & 28 & 30 \\
\hline Veenkoloniën en Oldambt & 49 & 45 & 43 & 42 & 40 & 44 \\
\hline Noordelijk weidegebied & 111 & 105 & 101 & 97 & 93 & 101 \\
\hline Oostelijk veehouderijgebied & 83 & 82 & 82 & 80 & 82 & 82 \\
\hline Centraal veehouderijgebied & 17 & 20 & 22 & 24 & 27 & 22 \\
\hline IJsselmeerpolders & 33 & 28 & 25 & 24 & 24 & 27 \\
\hline Westelijk Holland & 21 & 22 & 28 & 28 & 26 & 25 \\
\hline Waterland en Droogmakerijen & 23 & 25 & 23 & 21 & 24 & 23 \\
\hline Hollands/Utrechts weidegebied & 31 & 31 & 29 & 28 & 29 & 30 \\
\hline Rivierengebied & 22 & 22 & 21 & 21 & 21 & 21 \\
\hline Zuidwestelijk akkerbouwgebied & 46 & 45 & 44 & 46 & 46 & 45 \\
\hline Zuidwest-Brabant & 20 & 20 & 21 & 21 & 20 & 20 \\
\hline Zuidelijk veehouderijgebied & 60 & 62 & 66 & 64 & 67 & 64 \\
\hline Zuid-Limburg & 28 & 27 & 27 & 32 & 28 & 28 \\
\hline Nederland & 577 & 566 & 560 & 556 & 555 & 563 \\
\hline
\end{tabular}

Bron: LEI Wageningen UR.

Statistical Matching en dekking productiecapaciteit

Met de methode 'Statistical Matching' worden bij elk bedrijf uit de CBS-Landbouwtelling de drie 'best passende' steekproefbedrijven gezocht. Die matching is uitgevoerd op basis van:

1. De veertien landbouwgebieden, harde voorwaarde (exacte match)

2. Bedrijfstypen, harde voorwaarde (exacte match)

3. Bedrijfsomvang (SO) (beste match)

4. Oppervlakte cultuurgrond (beste match)

5. So per hectare landbouwgrond (beste match). 
Voor melkveebedrijven zijn aanvullend nog gebruikt:

1. Aandeel grasland van de cultuurgrond (beste match)

2. Aantal melkkoeien (beste match)

Voor elk bedrijf in de Landbouwtelling van voornoemde omvang zijn de drie matchings uit het Informatienet gewogen op basis van de afstand (niet fysiek, maar naar gelijkenis) tot het Landbouwtellingsbedrijf. Hoe kleiner de afstand, hoe zwaarder het betreffende steekproefbedrijf wordt meegenomen voor het betreffende Landbouwtellingsbedrijf. De SO wordt gezien als het belangrijkste vergelijkingscriterium en wordt, bij het bepalen van de afstand, zwaarder meegewogen (5:1) dan de andere kengetallen. Op basis van deze weging wordt met behulp van bovengenoemde steekproefbedrijven in elk pachtprijsgebied de productiecapaciteit (SO) uit de landbouwtelling in 2014 voor 95 tot $105 \%$ gedekt (Tabel B.2).

\section{Tabel B.2}

Mate waarin de gemiddelde SO uit de landbouwtelling wordt gedekt door de gewogen SO van de steekproefbedrijven naar pachtprijsgebied, 2010-2014.

\begin{tabular}{|c|c|c|c|c|c|}
\hline Pachtprijsgebied & 2010 & 2011 & 2012 & 2013 & 2014 \\
\hline Bouwhoek en Hogeland & 98 & 101 & 100 & 99 & 101 \\
\hline Veenkoloniën en Oldambt & 100 & 100 & 99 & 99 & 99 \\
\hline Oostelijk veehouderijgebied & 100 & 100 & 99 & 100 & 100 \\
\hline Centraal veehouderijgebied & 96 & 94 & 95 & 97 & 95 \\
\hline Westelijk Holland & 97 & 97 & 98 & 97 & 99 \\
\hline Waterland en Droogmakerijen & 97 & 94 & 94 & 95 & 95 \\
\hline Hollands/Utrechts weidegebied & 99 & 99 & 98 & 99 & 99 \\
\hline Rivierengebied & 92 & 93 & 97 & 95 & 95 \\
\hline Zuid-Limburg & 94 & 95 & 97 & 98 & 98 \\
\hline Nederland & 99 & 99 & 99 & 99 & 100 \\
\hline
\end{tabular}

Bron: LEI Wageningen UR.

\section{Berekening grondbeloning}

De berekening van de grondbeloning is gebaseerd op het kengetal bedrijfswinst uit normale bedrijfsvoering. Dat kengetal komt nagenoeg overeen met het 'inkomen uit bedrijf' dat het LEI als centraal kengetal publiceert in de monitoring van resultaten. Het verschil zit in de buitengewone baten en lasten, zoals boekverschillen en schade-uitkeringen, die jaarlijks per bedrijf sterk kunnen fluctueren.

In de resultaten die het LEI publiceert, wordt een post 'omzet en aanwas' als opbrengsten meegenomen, waarin ook de prijsmutatie van de biologische activa is opgenomen. Die prijsmutatie van de veestapel was in 2007 sterk positief door oplopende melkprijzen. In de berekening van de grondbeloning is die prijsmutatie, in overleg met het ministerie van EZ en de LTO, voor alle jaren uit het resultaat gerekend door ze als inkomenscorrectie van het inkomen af te trekken.

Een tweede inkomenscorrectie betreft de afschrijvingskosten van het melkquotum. Deze kosten worden op advies van de Commissie Pachtnormen II niet meegenomen in de berekening van de grondbeloning.

De reservering is gebaseerd op $20 \%$ van de vergoeding voor grond, grondbeloning I (Tabel B.3). De reservering wordt jaarlijks voor elk bedrijf vastgesteld. Als de vergoeding voor grond I negatief is, is de reservering op nul gesteld. 


\section{Resultaten totale groep}

Per saldo schommelt de berekende vergoeding voor grond II (grondbeloning na reservering) per jaar tussen 791 euro per hectare in 2014 en 1.132 euro per hectare in 2013 (Tabel B.3). Over deze onderzoeksperiode komt de gemiddelde vergoeding voor grond II uit op 939 euro per hectare. Dat gemiddelde is berekend door de vergoeding voor grond II (euro per bedrijf) te delen door de oppervlakte cultuurgrond (ha). De gemiddelden over 2010-2014 zijn berekend door de jaargemiddelden te wegen met het aantal bedrijven per jaar.

\section{Tabel B.3}

Berekeningswijze en uitkomsten van de grondbeloning op akkerbouw- en melkveebedrijven in Nederland (euro per bedrijf respectievelijk per hectare cultuurgrond), 2010-2014.

\begin{tabular}{|c|c|c|c|c|c|c|c|}
\hline & Omschrijving & 2010 & 2011 & 2012 & 2013 & 2014 & Gemiddeld \\
\hline & Aantal steekproefbedrijven & 577 & 566 & 560 & 556 & 555 & 563 \\
\hline & Aantal gerepresenteerde bedrijven & 16.698 & 16.475 & 16.320 & 17.699 & 17.621 & 16.963 \\
\hline & Bedrijfsomvang in SO (x 1.000) & 286 & 289 & 293 & 333 & 340 & 307 \\
\hline & Aantal melkkoeien & 73 & 74 & 76 & 75 & 67 & 73 \\
\hline & Bedrijfswinst normale bedrijfsvoering & 66.342 & 57.790 & 57.511 & 66.041 & 50.629 & 59.654 \\
\hline$(-)$ & Inkomenscorrectie & -16.772 & -17.693 & -17.836 & -17.775 & -18.432 & -17.710 \\
\hline$(+)$ & Betaalde pacht & 12.586 & 13.030 & 12.736 & 12.985 & 13.616 & 12.998 \\
\hline$(+)$ & Financieringslasten & 32.553 & 34.327 & 33.956 & 30.805 & 32.081 & 32.705 \\
\hline$(-)$ & Kosten quotum & 2.388 & 1.315 & 456 & 340 & 0 & 884 \\
\hline$(=)$ & Vergoeding voor grond I & 67.660 & 65.668 & 72.006 & 80.180 & 57.939 & 68.702 \\
\hline$(-)$ & Reservering & 14.468 & 14.274 & 15.250 & 16.513 & 12.919 & 14.686 \\
\hline \multirow[t]{6}{*}{$(=)$} & Vergoeding voor grond II & 53.192 & 51.395 & 56.756 & 63.666 & 45.020 & 54.017 \\
\hline & Euro per ha & & & & & & \\
\hline & Bedrijfswinst normale bedrijfsvoering & 1.152 & 990 & 983 & 1.174 & 889 & 1.037 \\
\hline & Vergoeding grond/vermogen/eigen arbeid & 2.227 & 2.105 & 2.085 & 2.268 & 2.016 & 2.139 \\
\hline & Vergoeding voor grond I & 1.175 & 1.125 & 1.230 & 1.425 & 1.018 & 1.194 \\
\hline & Vergoeding voor grond II & 924 & 881 & 970 & 1.132 & 791 & 939 \\
\hline
\end{tabular}

Bron: LEI Wageningen UR.

\section{B1.2 Los tuinland}

\section{Gebruikte steekproefbedrijven en weging}

Elk opengrondstuinbouwbedrijf met een omvang van 155.000 tot 885.000 SO met maximaal $25 \%$ niet-grondgebonden opbrengsten dient door bedrijven uit het Informatienet te worden gerepresenteerd. Daartoe zijn uit het Informatienet steekproefbedrijven met een omvang van 110.700 tot 974.250 SO van de bedrijfstypen bloembollen, opengrondsgroenten en boomkwekerij (exclusief bedrijven die meer dan 25\% grondgebonden opbrengsten realiseren) geselecteerd. In Westelijk Holland resulteerde dat in gemiddeld 23 Informatienetbedrijven en in Rest van Nederland in gemiddeld 39 Informatienetbedrijven in de periode 2010-2014 (Tabel B.4). 
Tabel B.4

Aantal gebruikte opengrondstuinbouwbedrijven (exclusief witloftrekbedrijven) in het Informatienet, 2010-2014.

\begin{tabular}{lrrrrrrr} 
Pachtprijsgebied & 2010 & 2011 & 2012 & 2013 & 2014 & Gemiddeld \\
Westelijk Holland a) & 22 & 23 & 22 & 21 & 28 & 23 \\
\hline Rest van Nederland & 34 & 39 & 38 & 36 & 47 & 39 \\
\hline
\end{tabular}

a) Exclusief boomkwekerij in het landbouwgebied Boskoop en Rijneveld. Bron: LEI Wageningen UR.

De koppeling met de Landbouwtelling op basis van gebied, type, jaar (exacte match), so, so per hectare en oppervlakte (beste match) is met de methode STARS op vergelijkbare manier gerealiseerd als in het geval van akkerbouw- en melkveebedrijven. Op basis van deze weging wordt met de bovengenoemde steekproefbedrijven in elk pachtprijsgebied de productiecapaciteit (SO) uit de Landbouwtelling voor 87 tot $110 \%$ gedekt (Tabel B.5).

\section{Tabel B.5}

Mate waarin de gemiddelde SO uit de landbouwtelling wordt gedekt door de gewogen SO van de steekproefbedrijven, 2010-2014.

\begin{tabular}{lrrrrr} 
Pachtprijsgebied & 2010 & 2011 & 2012 & 2013 & 97 \\
Westelijk Holland a) & 108 & 103 & 101 & 97 \\
\hline Rest van Nederland & 102 & 103 & 111 & 98
\end{tabular}

a) Exclusief boomkwekerij in het landbouwgebied Boskoop en Rijneveld.

Bron: LEI Wageningen UR.

\section{Berekening grondbeloning per pachtprijsgebied}

Ook voor de opengrondstuinbouwbedrijven is de reservering gebaseerd op $20 \%$ van de vergoeding voor grond I (zie de tabellen B.6 en B.7). De reservering wordt jaarlijks voor elk bedrijf vastgesteld. Indien de vergoeding voor grond I negatief is, is de reservering op nul gesteld. De resultaten zijn voor Westelijk Holland in Tabel B.6 en die van Rest van Nederland in Tabel B.7 gepresenteerd. In Westelijk Holland bedraagt de grondbeloning na reservering gemiddeld 2.947 euro per hectare in de periode 2010-2014. In Rest van Nederland is de grondbeloning na reservering 1.192 euro per hectare. 
Tabel B.6

Gemiddelde resultaten van opengrondstuinbouwbedrijven in Westelijk Holland a), 2010-2014.

\begin{tabular}{|c|c|c|c|c|c|c|c|}
\hline & Omschrijving & 2010 & 2011 & 2012 & 2013 & 2014 & Gemiddeld \\
\hline & Aantal steekproefbedrijven & 22 & 23 & 22 & 21 & 28 & 23 \\
\hline & Aantal gerepresenteerde bedrijven & 377 & 361 & 286 & 350 & 325 & 340 \\
\hline & Oppervlakte cultuurgrond & 23,0 & 22,0 & 28,8 & 23,4 & 21,8 & 23,6 \\
\hline & Bedrijfsomvang in SO (x 1.000) & 461,4 & 440,9 & 417,0 & 447,0 & 379,4 & 431 \\
\hline & \multicolumn{7}{|l|}{ Euro per bedrijf } \\
\hline & Bedrijfswinst normale bedrijfsvoering & 96.936 & 38.662 & 119.679 & 107.892 & 64.367 & 84.409 \\
\hline$(-)$ & Inkomenscorrectie & 0 & -137 & 0 & 0 & -7 & -30 \\
\hline$(+)$ & Betaalde pacht & 41.042 & 31.097 & 41.313 & 33.907 & 33.025 & 35.971 \\
\hline$(+)$ & Financieringslasten & 49.260 & 48.077 & 44.601 & 41.490 & 40.957 & 45.035 \\
\hline$(=)$ & Vergoeding grond/vermogen/eigen arbeid & 187.238 & 117.973 & 205.593 & 183.288 & 138.355 & 165.446 \\
\hline$(-)$ & Kosten arbeid & 49.626 & 51.215 & 50.100 & 48.466 & 51.183 & 50.102 \\
\hline$(-)$ & Kosten vermogen & 33.602 & 28.966 & 21.381 & 21.172 & 24.253 & 26.211 \\
\hline$(-)$ & Kosten quotum & 37 & 23 & 3 & 3 & 0 & 14 \\
\hline$(=)$ & Vergoeding voor grond I & 103.972 & 37.769 & 134.109 & 113.647 & 62.919 & 89.119 \\
\hline$(-)$ & Reservering & 23.756 & 9.596 & 27.394 & 22.880 & 15.221 & 19.547 \\
\hline$(=)$ & Vergoeding voor grond II & 80.216 & 28.173 & 106.715 & 90.768 & 47.698 & 69.572 \\
\hline \multicolumn{8}{|c|}{ Euro per hectare } \\
\hline & Bedrijfswinst normale bedrijfsvoering & 4.223 & 1.754 & 4.154 & 4.620 & 2.950 & 3.575 \\
\hline & Vergoeding grond/vermogen/eigen arbeid & 8.157 & 5.353 & 7.136 & 7.848 & 6.341 & 7.007 \\
\hline & Vergoeding voor grond I & 4.530 & 1.714 & 4.655 & 4.866 & 2.883 & 3.774 \\
\hline & Vergoeding voor grond II & 3.495 & 1.278 & 3.704 & 3.887 & 2.186 & 2.947 \\
\hline
\end{tabular}

a) Exclusief boomkwekerij in het landbouwgebied Boskoop en Rijneveld.

Bron: LEI Wageningen UR.

\section{Tabel B.7}

Gemiddelde resultaten van opengrondstuinbouwbedrijven in Rest van Nederland, 2010-2014.

\begin{tabular}{|c|c|c|c|c|c|c|c|}
\hline & Omschrijving & 2010 & 2011 & 2012 & 2013 & 2014 & Gemiddeld \\
\hline & Aantal steekproefbedrijven & 34 & 39 & 38 & 36 & 47 & 39 \\
\hline & Aantal gerepresenteerde bedrijven & 1.248 & 1.245 & 1.181 & 1.161 & 1.229 & 1.213 \\
\hline & Oppervlakte cultuurgrond & 15,5 & 17,3 & 16,7 & 13,5 & 15,8 & 15,8 \\
\hline & Bedrijfsomvang in SO (x 1.000) & 386,5 & 390,2 & 417,9 & 371,8 & 407,3 & 395 \\
\hline & \multicolumn{7}{|l|}{ Euro per bedrijf } \\
\hline & Bedrijfswinst normale bedrijfsvoering & 17.988 & 39.851 & 44.757 & 75.154 & 68.574 & 48.887 \\
\hline$(-)$ & Inkomenscorrectie & 0 & -64 & -61 & 0 & -52 & -36 \\
\hline$(+)$ & Betaalde pacht & 13.457 & 14.998 & 15.529 & 11.634 & 16.411 & 14.427 \\
\hline$(+)$ & Financieringslasten & 15.614 & 15.581 & 13.149 & 13.514 & 12.382 & 14.070 \\
\hline$(=)$ & Vergoeding grond/vermogen/eigen arbeid & 47.059 & 70.494 & 73.496 & 100.302 & 97.420 & 77.420 \\
\hline$(-)$ & Kosten arbeid & 37.224 & 36.857 & 36.807 & 35.883 & 35.462 & 36.454 \\
\hline$(-)$ & Kosten vermogen & 21.078 & 13.039 & 8.340 & 9.337 & 9.281 & 12.308 \\
\hline$(-)$ & Kosten quotum & 22 & 22 & 7 & 2 & 0 & 11 \\
\hline$(=)$ & Vergoeding voor grond I & -11.265 & 20.576 & 28.341 & 55.080 & 52.677 & 28.647 \\
\hline$(-)$ & Reservering & 4.329 & 9.538 & 9.528 & 12.909 & 13.049 & 9.821 \\
\hline \multirow[t]{6}{*}{$(=)$} & Vergoeding voor grond II & -15.594 & 11.038 & 18.813 & 42.172 & 39.628 & 18.826 \\
\hline & Euro per hectare & & & & & & \\
\hline & Bedrijfswinst normale bedrijfsvoering & 1.158 & 2.307 & 2.675 & 5.547 & 4.337 & 3.094 \\
\hline & Vergoeding grond/vermogen/eigen arbeid & 3.030 & 4.081 & 4.392 & 7.404 & 6.162 & 4.900 \\
\hline & Vergoeding voor grond I & -725 & 1.191 & 1.694 & 4.066 & 3.332 & 1.813 \\
\hline & Vergoeding voor grond II & -1.004 & 639 & 1.124 & 3.113 & 2.506 & 1.192 \\
\hline
\end{tabular}

Bron: LEI Wageningen UR. 
LEI Wageningen UR

Postbus 29703

2502 LS Den Haag

T 0703358330

E publicatie.lei@wur.nl

www.wageningenUR. nl/lei

Nota

LEI 2016-053
LEI Wageningen UR is een onafhankelijk, internationaal toonaangevend, sociaaleconomisch onderzoeksinstituut. De unieke data, modellen en kennis van het LEI bieden opdrachtgevers op vernieuwende wijze inzichten en integrale adviezen bij beleid en besluitvorming, en dragen uiteindelijk bij aan een duurzamere wereld. Het LEI maakt deel uit van Wageningen UR (University \& Research centre). Daarbinnen vormt het samen met het Departement Maatschappijwetenschappen van Wageningen University en het Wageningen UR Centre for Development Innovation de Social Sciences Group.

De missie van Wageningen UR (University \& Research centre) is 'To explore the potential of nature to improve the quality of life'. Binnen Wageningen UR bundelen 9 gespecialiseerde onderzoeksinstituten van stichting DLO en Wageningen University hun krachten om bij te dragen aan de oplossing van belangrijke vragen in het domein van gezonde voeding en leefomgeving. Met ongeveer 30 vestigingen, 6.500 medewerkers en 10.000 studenten behoort Wageningen UR wereldwijd tot de aansprekende kennisinstellingen binnen haar domein. De integrale benadering van de vraagstukken en de samenwerking tussen verschillende disciplines vormen het hart van de unieke Wageningen aanpak. 


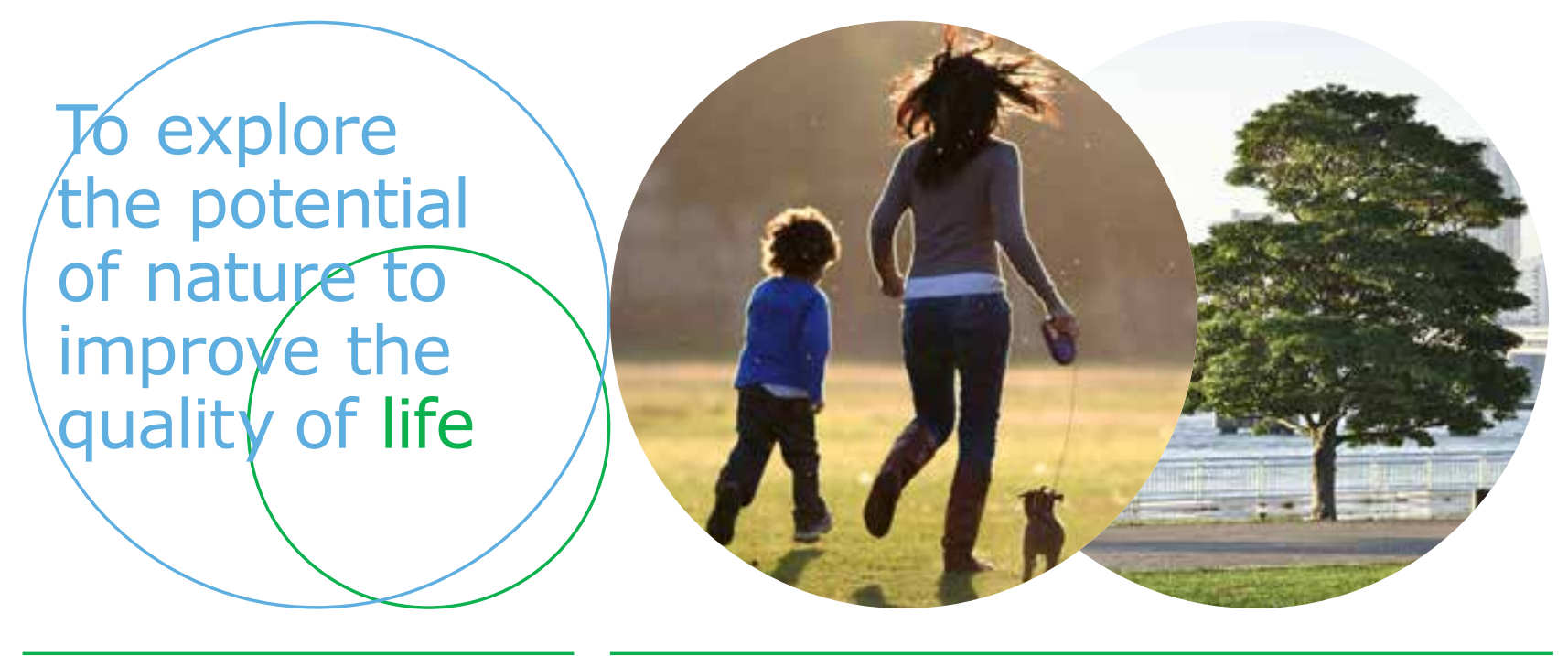

LEI Wageningen UR

Postbus 29703

2502 LS Den Haag

E publicatie.lei@wur.nl

www.wageningenUR.nl/lei

NOTA

LEI 2016-053
LEI Wageningen UR is een onafhankelijk, internationaal toonaangevend, sociaaleconomisch onderzoeksinstituut. De unieke data, modellen en kennis van het LEI bieden opdrachtgevers op vernieuwende wijze inzichten en integrale adviezen bij beleid en besluitvorming, en dragen uiteindelijk bij aan een duurzamere wereld. Het LEI maakt deel uit van Wageningen UR (University \& Research centre). Daarbinnen vormt het samen met het Departement Maatschappijwetenschappen van Wageningen University en het Wageningen UR Centre for Development Innovation van de Social Sciences Group.

De missie van Wageningen UR (University \& Research centre) is 'To explore the potential of nature to improve the quality of life'. Binnen Wageningen UR bundelen 9 gespecialiseerde onderzoeksinstituten van stichting DLO en Wageningen University hun krachten om bij te dragen aan de oplossing van belangrijke vragen in het domein van gezonde voeding en leefomgeving. Met ongeveer 30 vestigingen, 6.500 medewerkers en 10.000 studenten behoort Wageningen UR wereldwijd tot de aansprekende kennisinstellingen binnen haar domein. De integrale benadering van de vraagstukken en de samenwerking tussen verschillende disciplines vormen het hart van de unieke Wageningen aanpak. 